\title{
Factors affecting the intention to purchase halal cosmetics on Instagram: E-WOM and brand image
}

\author{
Muhammad Farid Wajdi, Hendy Mustiko Aji*, Suwarsono \\ Department of Management, Faculty of Business and Economics, Universitas \\ Islam Indonesia, Yogyakarta, Indonesia \\ *Corresponding author: hm.aji@uii.ac.id
}

Article History

Received, 03 June 2020 Revised 1, 04 June 2020 Revised 2, 06 June 2020 Accepted, 10 June 2020

\begin{abstract}
Purpose: This research is conducted to understand the effect of E-WOM and brand image on purchase intention of halal cosmetics which are sold online through Instagram.
\end{abstract}

Methodology: This research is quantitative research. The data used in this research is primary data which is collected using a questionnaire. The sampling technique is purposive sampling with 93 research samples.

Findings: This research shows that the purchase intention of halal cosmetics through Instagram is simultaneously influenced by E-WOM and brand image. This finding support previous researches related to the effect of E-WOM and brand image on purchase intention.

Originality/Value: This research is a replication-based model and is adapted from published research. The originality in this research is in the context of object and location. Various halal cosmetics that are being sold online through Instagram are the main focus to be researched on. This main focus has not been being researched beforehand.

Keywords: Electronic Word of Mouth, brand image, purchase intention.

Cite this:

Wajdi, M F., Aji, H M., \& Suwarsono. (2020). Factors affecting the intention to purchase halal cosmetics on instagram: E-WOM and brand image. Asian Journal of Islamic Management, 1(2), 1-11. DOI: 10.1108/AJIM.vol2.iss1.art1

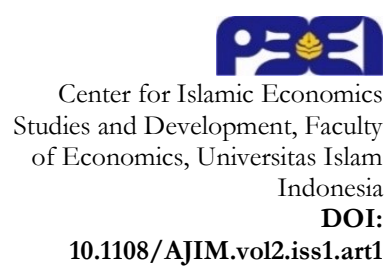

\section{Introduction}

Social media has power on its strong and rich content as consumers' references on getting information about a certain product. This content power and discussion that happen within the social media ecosystem push companies to take advantage of it as their marketing and communication mean. As this occurred, the company should understand how consumers behave toward their product in the market. Creating positive responses through online judgment can be a factor influencing consumers' purchase intention (Jalilvand \& Samiei, 2012).

Instagram is a social media that is very often accessed by the internet user. Based on data by Wahyunanda (2019), a Warsaw-based social media marketing analytics company stated that Indonesian Instagram active users are up to 61.610 .000 users by November 2019. This number increases from 59.840.000 from the previous month. It is known that women users are dominating with the percentage of $50.8 \%$ while men users are up to $49.2 \%$ in percentage. From the age category, Indonesian Instagram users are dominated by a group of 18-24 years old with a total percentage of $37.3 \%$ or up to 23 million users in number. The second-largest Indonesian Instagram 
users are those included in the 25-34 years old category. This group dominates as much as $33.9 \%$ of all Indonesian Instagram users. Surprisingly, there is this fact that shows men users are dominating in this age group category with a percentage of $17.9 \%$ (1.1 million higher in number than women users) compared to women users in this age group with only $16.1 \%$ in percentage. Subsequently, the facts bring the age group of $65+$ years old to the least active Indonesian Instagram users with only $1.6 \%$ of all users. Thus, this shows that most Indonesian Instagram users are young people who will probably follow their favorite brands and it should be a good opportunity for marketers (Hamidun, 2018).

As social beings, humans like to build relationships based on communication with another. This fact leads to a finding that information spread through WOM will likely to be more trusted. Furthermore, from time to time, this WOM method is developing and going online which becomes e-WOM (Hamidun, 2018). Companies then use this trend as their new way of marketing and communication. A negative review from consumers will also lead to a bad brand image of a product. This new form of WOM is now becoming an important factor in shaping consumer behavior. Online recommendations and reviews given by other users in a sharing review platform or online community may affect consumers' purchase intention (Jalilvand, M.R. \& Samiei, 2012).

Research about electronic word-of-mouth (e-WOM) by Jalilvand \& Samiei (2012) shows that brand image affects consumer purchase intention in the Iranian car industry. They proved that e-WOM has a positive effect on purchase intention and brand image. Bataineh (2015) researched and proved that e-WOM affects purchase intention with Amman's company reputation as the mediation. It is proven also that e-WOM positively company reputation. Suwarduki, Yulianto \& Mawardi (2016) researched the relationship between e-WOM and destination brand image toward visiting decisions on tourist destinations in Indonesia. The research shows that e-WOM has a positive impact on visiting decision. It is known that this visiting decision is influenced by e-WOM distributed by Indratrevel account on Instagram so that consumers, Indratrevel followers, feel encouraged to visit a certain destination. Laksmi and Oktafani (2016) find out that e-WOM has a positive effect on consumer purchase intention. Their research was conducted to understand Warunk Upnormal Bandung's Instagram followers' purchase intention. Putra, Tanamal \& Mubarok (2016) stated in their research that Instagram e-WOM has a positive impact on Battleboom Palu consumers' purchase intention. Erkan \& Evans (2016) also find out that in social media, e-WOM is proven to have a positive impact on purchase intention.

Hamidun (2018) researched how e-WOM affects purchase intention through the brand image, and it is proven by the research that there is a positive effect of e-WOM on purchase intention. The object of the research is the ouvalresearch Instagram account. It is known that the intention to purchase is caused by the account's encouragement so that the account's followers feel pushed to purchase the product. On the other side, branding is considered as an important mission to companies. A strong brand image may lead to higher trust from consumers. E-WOM can be one of the means to create a stronger brand image. Consumers' tendency to buy a product could be higher when they are driven by specific motivations. Further, satisfied consumers will spread word-of-mouth recommendations to their community which then can be advantageous to the companies and the product brand images (Ratnawati, Putranti, \& Pradana, 2015).

The main problems discussed in this research are supported by researches from Baiteneh (2015) and Hamidun (2018) about brand image and company reputation. Consumers now cannot differentiate between brand image and company reputation. As in the case of Coca-Cola, when the company's product name is the same as the holding company's name, it will confuse consumers, thus, they are not able to see the difference between brand image and company reputation. In Indonesia, the same case happens as well for brands like Aqua, Yakult, and Wardah. Seeing the development, growth, and opportunity within the Indonesian internet user ecosystem, halal cosmetic companies are racing to use Instagram as their promotion means. Through Instagram features like the repost feature, information spreading can be easier. 


\section{Literature Review and Hypotheses Development}

\section{The Effect of E-WOM on Purchase Intention}

WOM is considered as an effective marketing strategy because of its direct effect on a potential consumer. WOM can stimulate consumers' desire to buy something or purchase intention. When consumers have this purchase intention it can be said that they already trust the product thus they want to purchase the product. Purchase intention is very much related to buying decisions. The more the purchase intention, the higher consumer will likely buy the product. Marketers' role, in this case, is very important to evaluate promotion strategies that have been established and to align them with the company's long term sustainability (Putri, Kumadhii, \& Sunarti, 2016).

When a consumer buys a product, usually, they will seek information related to the product before the purchase (Kotler \& Armstrong, 2012). Today in this digital era, not only consumers can get information from advertisements and WOM, but also from other consumers' reviews and discussion through the internet. This particular review and discussion are called electronic wordof-mouth (e-WOM). Goldsmith (2008) stated that a logic, persuasive, and fact-based e-WOM will likely have a more positive impact on consumers' purchase intention. Goldsmith also added that e-WOM quantity also has a positive impact on consumers' purchase intention. Cheung \& Lee (2012) in their research find that e-WOM has a significant impact on consumers' purchase intention. The research is conducted on an online forum and it is known that e-WOM has a positive $20 \%$ impact on purchase intention with various indicators. Jalilvand, Reza \& Samiei (2012) find similar results on their research that it is known that e-WOM has a direct and indirect impact on consumer purchase intention. Thus, based on the findings, it can be developed that the first hypothesis of this research is:

H1: e-WOM has a positive impact on purchase intention.

\section{The Effect of E-WOM on Brand Image}

A positive brand image will be easier to be created in consumers' perception when it is supported by positive e-WOMs, while the same goes for the negative ones. A bad brand image may be influenced by the spreading of negative e-WOMs (Herr et al, 1991). Further, a better brand image may lead to better product quality perception and vice versa. Positive word-of-mouth can form a better product quality perception, meanwhile negative word-of-mouth will form a worse product quality perception (Herr et al, 1991).

Jalilvand (2012) finds that there is a significant impact of e-WOM on brand image. Based on his research on car industries in Iran, it is known that e-WOM effectively affect consumers' brand image creation. Riyandika (2013) also stated that e-WOm has a positive impact on brand image. According to his research, the more consumers seek information, their brand image perception of a product will be easier to be influenced. Hamidun (2018), in his research, stated that e-WOM has a significant impact on brand image and this is caused by consumers' behavior on social media. According to the research, the brand image of RSCH is created on consumers' perceptions after they are seeing comments related to RSCH in the Ouvalresearch Instagram account. Based on the findings, the second hypothesis of this research is:

H2: e-WOM has a positive impact on brand image.

\section{The Effect of Brand Image on Purchase Intention}

According to Jalilvand \& Samiei (2012), WOM plays an important role in influencing consumers' attitudes and behavior. It is stated also that WOM creates a strong effect on purchase intention compared to other traditional communication means, either advertisement or editorial recommendation. According to Hamidun (2018), brand image is an identity, perception, big picture, or impression created by companies to differentiate their products with others through collecting information from various sources. 
Jalilvand (2012) finds out that brand image has a direct effect on purchase intention, while e-WOM has an indirect effect on purchase intention. Riyandika (2013) also finds the same result in his research that brand image has a positive effect on purchase intention. He stated that when a product is being recommended through e-WOM spreading, it will cause purchase intention on that product. Hamidun (2018), in his research, stated that brand image has a significant impact on purchase intention. This is caused by the existence of credibility and followers' trust of an Instagram account (Ouvalresearch), thus, this leads to purchase intention on Ouvalresearch's product. Based on the findings, the third hypothesis in this research is:

H3: Brand image has a positive effect on purchase intention.

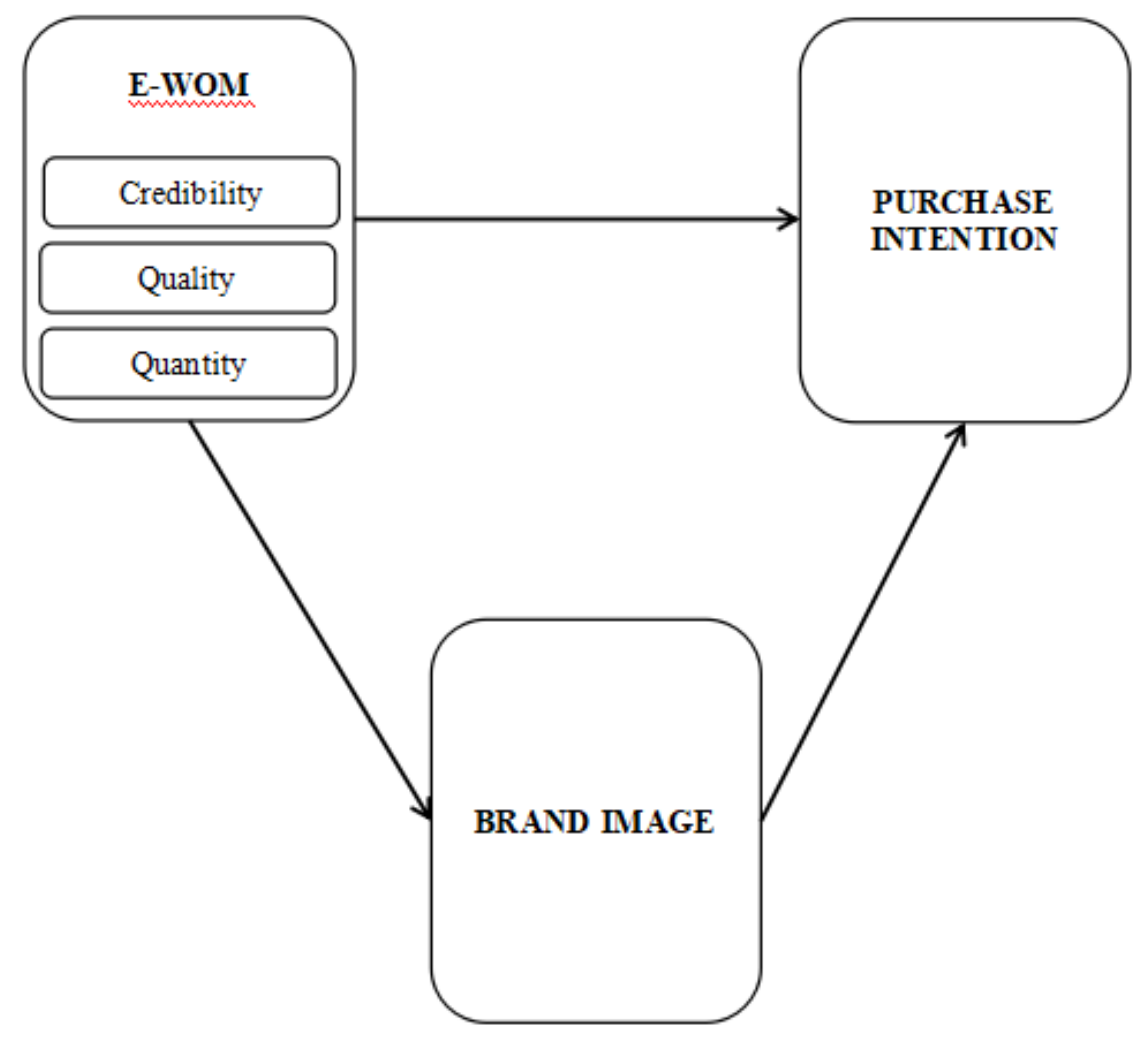

Figure 2.1 Research Model Adopted from: Baiteneh (2015) dan Hamidun (2018)

\section{Methods}

\section{Operational Definition of Research Variable}

\section{Electronic word-of-mouth}

Electronic word-of-mouth is either a positive or negative statement related to halal cosmetics spread by consumers and given through the comments section or reviewing platform on social media. This, then, will support the occurrence of discussion and form an e-WOM. In this research, e-WOM is measured using 11 indicators adopted from Baiteneh (2015) as follows:

a. E-WOM Credibility

1. Internet users who review halal cosmetics are trustworthy.

2. Internet users who review halal cosmetics are reassuring.

3. I feel helped by internet users' reviews on Instagram about halal cosmetics brand.

4. Internet users give honest reviews on Instagram about the halal cosmetics brand.

b. E-WOM Quality

1. The reviews given by internet users on Instagram about halal cosmetics brands are very clear. 
2. The reviews given by internet users on Instagram about halal cosmetics brands are understandable.

3. The reviews given by internet users on Instagram about halal cosmetics brands are precise.

4. The reviews given by internet users on Instagram about halal cosmetics brands are very helpful.

c. E-WOM Quantity

1. The reviews given by internet users on Instagram about halal cosmetics brands are plenty enough.

2. The reviews given by internet users on Instagram about halal cosmetics brands are usually positive.

3. Many reviews on Instagram recommend to purchase certain halal cosmetics brand.

\section{Brand Image}

Brand image is an impression related to halal cosmetics brand arises in the consumers' mind. The more associated the impression of the related halal cosmetics brand, the stronger the brand image shaped. In this research, brand image is measured by 5 indicators adopted by Debrina (2017), that are: (1) halal cosmetics brand is easy to be recognized; (2) halal cosmetics brand is easy to be remembered; (3) halal cosmetics brand is well-known; (4) halal cosmetics brand varies.

\section{Purchase Intention}

Purchase intention is consumers desire to fulfill their needs and wants related to halal cosmetics, where the desire comes from the activity of collecting information which then encourages them to have the product. In this research, purchase intention is measured by 11 indicators adopted from Baiteneh (2015). The indicators are: (1) after reading halal cosmetics reviews on Instagram, I want to buy the product; (2) after reading halal cosmetics reviews on Instagram, I consider to buy the product in the future; (3) after reading halal cosmetics reviews on Instagram, I am likely to buy the product; (4) if I have the chance, I will buy the halal cosmetics product.

\section{Sampling Technique and Data Collection}

The method used in this research is a non-probability sampling with purposive sampling as the sampling technique. The criteria used to determine the respondents are: (1) respondent must be a college student domiciled in Yogyakarta; (2) respondent must be an active Instagram user. According to Malhotra (2006), the number of samples should be four or five times the number of question items. Thus, in this research, 100 samples are needed as the number of question items is $20(20 \times 5=100)$. The questionnaire is spread using online and offline media and made with Google Forms. The offline questionnaire is distributed to places like campuses and public areas around Yogyakarta. The criteria of halal cosmetics used as the object in this research are: (1) have halal certification from MUI; (2) used no haram materials in the product like pork, dogs, and alcohol; (3) the cosmetics must not prevent the ablution water from entering the skin. Thus, the chosen halal cosmetics brands are Wardah, Sariayu, MakeOver, Purbasari, L'Oreal, Nivea, and others. The measurement for this research is Likert scale with a specific range of $1=$ totally disagree up to $5=$ totally agree.

\section{Results}

\section{Validity and Reliability Test}

The validity test in this research is conducted using a dimension reduction technique (factor analysis) with SPSS as the analysis tool. The KMO Bartlett test in this research is 0.867 which is greater than 0.50 and shows that the sample of the research is sufficient and proper to tested using factor analysis. The reliability test is to determine whether the indicator used in the research is 
reliable. A questionnaire is considered reliable if respondents' responses are stable from time to time. This research is using SPSS 2020 with the Cronbach Alpha coefficient method to test the reliability. According to Ghozali (2006), a variable is considered reliable if the Cronbach Alpha value is greater than 0.60 . Based on the test, the variables score for validity and reliability scores are as follows:

Table 1. Validity and Reliability Test

\begin{tabular}{llcccc}
\hline Variable & Indicator & Loading Factor & Description & KMO & Alpha \\
\hline \multirow{6}{*}{ CRED 1 } & 0,608 & Valid & & \\
E-WOM & CRED 2 & 0,637 & Valid & & \\
CRED 4 & 0,755 & Valid & & \\
QUAL 1 & 0,769 & Valid & & \\
QUAL 2 & 0,856 & Valid & & \\
& QUAL 3 & 0,699 & Valid & & \\
QUAL 4 & 0,639 & Valid & & \\
QUANT 1 & 0,656 & Valid & & \\
QUANT2 & 0,586 & Valid & & \\
QUANT 3 & 0,514 & Valid & 0.867 & \\
Brand Image & IMG 1 & 0,882 & Valid & & \\
& IMG 2 & 0,844 & Valid & & \\
IMG 3 & 0,848 & Valid & & \\
& IMG 4 & 0,655 & Valid & & \\
IMG5 & 0,667 & Valid & & \\
Purchase Intention & INT1 & 0,584 & Valid & & \\
& INT2 & 0,679 & valid & & \\
& INT3 & 0,843 & valid & & \\
& INT4 & 0,748 & valid & & \\
\hline
\end{tabular}

Source: Primary Data, 2020

\section{Respondent Descriptive}

In total, this research used as much as 93 respondent data that is collected through an online questionnaire. Based on the data, in the demographics section, women dominate as much as $92.5 \%$ compared to men that are only $7.5 \%$ in percentage. In the age category, the respondents are dominated by those who are, first, 21-24 years old (49.5\%), secondly, 17-20 years old (44.1\%) and above 24 years old $(6.4 \%)$. Meanwhile, the data shows that up to $98.9 \%$ of the respondents are active Instagram users and the other $1.1 \%$ are not. The number of respondents who follow halal cosmetics brands Instagram accounts is $59.1 \%$ while the other $40.9 \%$ admitted to not following any halal cosmetics brand Instagram accounts. Further, from its occupation, it is known that $92.5 \%$ of the respondents are college students and the other $7.5 \%$ are not as shown in Table 2 . Based on their incomes, the respondents are dominated by those with income under Rp1.000.000,- (51.6\%) followed by those with income Rp1.000.001-Rp2.000.000,- (40.9\%), above Rp3.000.000,- (4.3\%) and Rp2.000.001-Rp3.000.000,- (3.2\%).

The data shows that the majority of respondents follow several halal cosmetics Instagram accounts like Wardah (62\%), Emina (10\%), Purbasari (1\%), Safi (8\%), botanicabeauty.id (1\%), Pixy $(3 \%)$, Zalfa (1\%), Suastika Skincare (1\%), MakeOver (2\%), Maybelline (1\%), Viva (1\%), Mizzu $(1 \%)$, Natasha $(1 \%)$, and YOU $(1 \%)$. In total, 71 respondents follow halal cosmetics brand Instagram accounts. The data are shown in Table 3. 
Tabel 2. Respondents Demographics

\begin{tabular}{|c|c|c|}
\hline Demographic Variables & Number & $\%$ \\
\hline \multicolumn{3}{|l|}{ Gender } \\
\hline Female & 86 & $92,5 \%$ \\
\hline Male & 7 & $7,5 \%$ \\
\hline \multicolumn{3}{|l|}{ Ages } \\
\hline $17-20$ years old & 41 & $44,1 \%$ \\
\hline 21-24 years old & 46 & $49,5 \%$ \\
\hline$>24$ years old & 6 & $6,4 \%$ \\
\hline \multicolumn{3}{|l|}{ Instagram user } \\
\hline Active & 92 & $98,9 \%$ \\
\hline Inactive & 1 & $1,1 \%$ \\
\hline \multicolumn{3}{|c|}{ Are they following halal cosmetic brands on Instagram? } \\
\hline Yes & 55 & $59,1 \%$ \\
\hline No & 38 & $40,9 \%$ \\
\hline \multicolumn{3}{|l|}{ Occupation } \\
\hline College student & 86 & $92,5 \%$ \\
\hline Non-college student & 7 & $7,5 \%$ \\
\hline \multicolumn{3}{|l|}{ Income } \\
\hline$<1.000 .000$ & 48 & $51,6 \%$ \\
\hline $1.000 .001-2.000 .000$ & 38 & $40,9 \%$ \\
\hline $2.000 .001-3.000 .000$ & 3 & $3,2 \%$ \\
\hline$>3.000 .000$ & 4 & $4,3 \%$ \\
\hline
\end{tabular}

Source: Primary Data, 2020

Table 3. Instagram Followers

\begin{tabular}{clccc}
\hline No. & & Brand Name & $\begin{array}{c}\text { No. of Respondent } \\
\text { Following }\end{array}$ & $\%$ \\
\hline 1 & Wardah & 44 & $62 \%$ \\
2 & Emina & 7 & $10 \%$ \\
3 & Purbasari & 1 & $1 \%$ \\
4 & Safi & 6 & $8 \%$ \\
5 & botanicabeuaty.id & 1 & $1 \%$ \\
6 & Pixy & 2 & $3 \%$ \\
7 & Zalfa & 1 & $1 \%$ \\
8 & Suastika Skincare & 1 & $1 \%$ \\
9 & Make over & 2 & $3 \%$ \\
10 & Maybeline & 1 & $1 \%$ \\
11 & Viva & 1 & $1 \%$ \\
12 & Oriflame & 1 & $1 \%$ \\
13 & Natasha & 1 & $1 \%$ \\
14 & YOU & 1 & $1 \%$ \\
15 & Mizzu & 1 & $100 \%$ \\
\hline
\end{tabular}

Source: Primary Data, 2020

\section{Classic Assumption Test}

The significance value of the Kolmogorov-Smirnov test (p) in this research is $0.007>0.05$, then the data is considered normally distributed. The Saphiro-Wilk test also shows the same result which is $0.02>0.05$ and the data is considered normally distributed. As shown in Table 4, the tolerance value of X1 and X2 is greater than 0.10, which is 0.693 , and the VIF value of X1 and X2 is less than 10.00 , which are 1.444 , thus it can be considered that there is no multicollinearity in the regression 
model. Further, as in Table 4, that the Sig. values are greater than 0.05 which is 0.000 and 0.004 which means there is no heteroscedasticity in the regression model.

Table 4. Classic Assumption Test

\begin{tabular}{cccc}
\hline Model & Sig & Tolerance & VIF \\
\hline (Constant) &, 011 & & \\
X1 &, 000 &, 693 & 1,444 \\
X2 &, 004 &, 693 & 1,444 \\
\hline
\end{tabular}

Source: Primary Data, 2020

\section{Multiple Linear Regression Analysis}

The result of the regression analysis as in Table 5 shows that the sig. value are less than 0.05 which are 0.000 and 0.004 , thus it can be considered that the two variables of e-WOM and brand image have positive impacts on the purchase intention variable. Based on the estimation using multiple linear regression analysis, it is found the equation as follows:

$$
\mathrm{Y}=3.586+0,162 \mathrm{X} 1+0,232 \mathrm{X} 2+\mathrm{e}
$$

Thus, it can be concluded that every 1\% increase in e-WOM will add purchase intention value as much as 0.162 and every $1 \%$ increase in the brand image will add purchase intention value as much as 0.232 . if there are no e-WOM and brand image, the value of purchase intention will be 3.658.

Table 5. Multiple Linear Regression

\begin{tabular}{ccc}
\hline Model & T & Sig. \\
\hline (Constant) & 2,610 &, 011 \\
X1 & 3,772 &, 000 \\
X2 & 2,930 &, 004 \\
\hline
\end{tabular}

Source: Primary Data, 2020

Furthermore, an $\mathrm{F}$ test is conducted to determine whether there is a simultaneous e-WOM and brand image effect on purchase intention. The F test result, as in Table 6 , shows that the value of $\mathrm{F}$ count is 25.316 and the value of the significance (sig F) is 0.000 . Thus, it can be considered that the significance value is $0.000<0.05$, then $\mathrm{Ho}$ is rejected and $\mathrm{Ha}$ is supported or in the other words, there is a simultaneous effect of e-WOM and brand image on purchase intention. Subsequently, the R-Square value in this research is $0.379(37.9 \%)$ and it can be considered that the independent variable explains the dependant variable as much as $37.9 \%$ while the other $62.1 \%$ is explained by the other variables excluded in this research.

Table 6. F Test

\begin{tabular}{ccc}
\hline Model & F & Sig. \\
\hline Regression & 25,316 &, 000 \\
\hline Source: Primary Data, 2020 &
\end{tabular}

\section{Discussion}

The result of the multiple linear regression analysis shows that there is a significant effect of eWOM on the purchase intention of halal cosmetics. The result of the significance test using t test based on Table 5 is known as $0.00>0.05$, which means there is a positive and significant effect of e-WOM on purchase intention. The higher the e-WOM, the higher the purchase intention. By this fact, thus it is considered that the first hypothesis is supported. The result of this research is in line 
with the research of e-WOM and purchase intention within Iranian car industries by Jalilvand (2012).

The result of the multiple linear regression analysis shows that there is a significant effect of e-WOM on the brand image of halal cosmetics. The result of the significance test using $t$ test based on Table 5 is known as $0.00>0.05$, which means there is a positive and significant effect of $\mathrm{e}-\mathrm{WOM}$ on purchase intention. The higher the e-WOM, the higher the brand image. By this fact, thus it is considered that the second hypothesis is supported. The result of this research is in line with the research of e-WOM and brand image of Ouvalresearch Instagram account followers by Hamidun (2018).

The result of the multiple linear regression analysis shows that there is a significant effect of brand image on the purchase intention of halal cosmetics. The result of the significance test using t test based on Table 5 is known as $0.00>0.05$, which means there is a positive and significant effect of e-WOM on purchase intention. The higher the brand image, the higher the purchase intention. By this fact, thus it is considered that the third hypothesis is supported. The result of this research is in line with the research of e-WOM and brand image of Ouvalresearch Instagram account followers by Hamidun (2018).

\section{Conclusion}

Based on the findings and discussion it can be concluded that the purchase intention of halal cosmetics on Instagram is influenced by brand image and e-WOM.

\section{References}

APJII. (2018). BULETIN APJII. Asosiasi Penyelenggara Jasa Internet Indonesia, 1-7.

Assael, H. (2004). Consumer Behavior: A Strategic Approach. Boston: Houghton Mifflin Company.

Bataineh, A. Q. (2015b). The Impact of Perceived e-WOM on Purchase Intention: The Mediating Role of Corporate Image. 7(1), 126-138. https://doi.org/10.5539/ijms.v7n1p126

Bruyn, A. De, \& Lilien, G. L. (2008). Intern . J . of Research in Marketing A multi-stage model of word-ofmouth in fl uence through viral marketing is. 25, 151-163. https://doi.org/10.1016/j.ijresmar.2008.03.004

Chan, Y dan Ngai. (2011). Conceptualising electronic word of mouth activity An input-processoutput perspective, Marketing Intelegence and Planning, Vol 29/No 5, Mei, 488 - 516.

Cheung, C. M. K., \& Lee, M. K. O. (2012). What drives consumers to spread electronic word of mouth in online consumer-opinion platforms. Decision Support Systems, 53(1), 218-225. https://doi.org/10.1016/j.dss.2012.01.015

Daugherty, T., \& Hoffman, E. (2014). eWOM and the importance of capturing consumer attention within social media. Journal of Marketing Communications, Vol. 20, pp. 82-102. https://doi.org/10.1080/13527266.2013.797764

Debrina P. (2017). Pengaruh Brand Image dan Celebrity Endorser terhadap Keputusan Pembelian Kosmetik Wardah (Studi pada Mahasiswa Fakultas Ekonomi dan Bisnis Universitas Sumatera Utara) (Skripsi). Sumatera Utara (ID). Fakultas Ekonomi dan Bisnis Universitas Sumatera Utara.

Erkan, I., \& Evans, C. (2016). Computers in Human Behavior The in fl uence of eWOM in social media on consumers' purchase intentions: An extended approach to information adoption. Computers in Human Behavior, 61, 47-55. https://doi.org/10.1016/j.chb.2016.03.003

Evelina, Nela., Handoyo DW, Sari Listyorini. (2013). Pengaruh Citra Merek, Kualitas Produk, Harga, dan Promosi Terhadap Keputusan Pembelian Kartu Perdana Telkom Flexi (Studi 
Kasus pada Konsumen Telkom Flexi di Kecamatan Kota Kudus Kabupaten Kudus). Jurnal Ilmu Administrasi Bisnis,1(1), pp: 203-213.

Ferrinadewi, Erna. (2009). Merek \& psikologi konsumen: implikasi pada strategi pemasaran. Yogyakarta: Graha Ilmu.

Ferdinand, Augusty. (2014). Metode Penelitian Manajemen, Semarang, Badan Penerbit Universitas Diponegoro.

Ghozali, Imam. (2006). Aplikasi Analisis Multivariate Dengan Program SPSS. Cetakan Keempat. Semarang: Badan Penerbit Universitas Diponegoro.

Ghozali, Imam. (2011). “Aplikasi Analisis Multivariate Dengan Program SPSS”. Semarang: Badan Penerbit Universitas Diponegoro.

Goldsmith, R,. (2008). Electronic Word-ofMouth, E-commerce, Idea Group Reference Global, Florida.

Hamidun, M. A. (2018). Pengaruh Electronic Word Of Mouth Terhadap Purchase Intention Melalui Brand Image (Studi Pada Followers Akun Instagram@ Ouvalresearch).Jurnal Administrasi Bisnis, 61(2), 61-68.

Hennig-thurau, T., Eifler, V., Hennig-thurau, T., Gwinner, K. P., \& Gremler, D. D. (2004). Electronic Word-Of-Mouth Via Consumer-Opinion Platforms: What Motivates Consumers To Articulate Themselves On The Internet? Journal Of Interactive Marketing, 18(1), 38-52. https://doi.org/10.1002/dir.10073

Herr, P.M., Kardes, F.R., and Kim, L. (1991). Effects of word-of-mouth and product-attribute information on persuasion: An accessibility-diagnosticity perspective. Journal of Consumer Research. 17(4), 454-462.

Jalilvand, Mohamad Reza, \& Samiei, N. (2012). The effect of word of mouth on inbound tourists' decision for traveling to Islamic destinations (the case of Isfahan as a tourist destination in Iran). Journal of Islamic Marketing, 32(1), 12-21. https://doi.org/http://dx.doi.org/10.1108/MRR-09-2015-0216

Jalilvand, Mohammad Reza, \& Samiei, N. (2012). The effect of electronic word of mouth on brand image and purchase intention: An empirical study in the automobile. Marketing Intelligence \& Planning, 30(4460-476). https:// doi.org/10.1108/02634501211231946

Jansen, B. J., Zhang, M., Sobel, K., \& Chowdury, A. (2009). Twitter power: Tweets as electronic word of mouth. Journal of the American Society for Information Science and Technology.

Kotler, Philip dan Kevin Keller. (2009). Manajemen Pemasaran. Jilid 1. Edisi ke 13. Diterjemahkan oleh Bob Sabran. Jakarta: Erlangga.

Kotler, P. (2016). Manajemen Pemasaran. Jakarta: PT Indeks.

Kotler, P., \& Amstrong, G. (2012). Prinsip-Prinsip Pemasaran (12th ed.). Jakarta: Erlangga.

Keller, K. L. (1993). Conceptualizing, Measuring, and Managing Customer-Based Brand Equity. Journal of Marketing. 57. 1-22.

Laksmi, A. A., \& Oktafani, F. (2016). Pengaruh Electronic Word Of Mouth (Ewom) Terhadap Minat Beli Followers Instagram Pada Warunk Upnormal. Jurnal Computech Dan Bisnis, 10(2), 78-88.

Malhotra, Naresh K. (2006). Riset Pemasaran, Pendekatan Terapan. Edisi Keempat. Jilid 2. PT Indeks. Jakarta

Pradipta, Dyah Ayu Anisha. (2012). Pengaruh Citra Merek (Brand Image) Terhadap Loyalitas 
Konsumen Produk Oli Pelumas PT. Pertamina (Persero) Enduro 4T Di Makassar. Skripsi.Fakultas Ekonomi dan Bisnis Universitas Hasanuddin, Makasar.

Putra, C. A., Tanamal, J., \& Mubaraq, R. (2016). Pengaruh Electronic Word Of Mouth Di Media Sosial Instagram Terhadap Minat Beli Konsumen. Jurnal Ilmu Manajemen Universitas Tadalako, 1(3), 241-252.

Putri, F. C., Kumadji, S., \& Sunarti. (2016). Pengaruh Word Of Mouth Terhadap Minat Beli Dan Dampaknya Pada Keputusan Pembelian (Survei pada konsumen Legipait Coffeeshop Malang). Jurnal Administrasi Bisnis (JAB), 34(1), 86-95.

Ratnawati, H., Putranti, D., \& Pradana, F. D. (2015). Electronic Word Of Mouth (E-Wom), Kepuasan Konsumen Dan Pengaruh Langsung Dan Tak Langsung Terhadap Minat Beli Konsumen (Studi Pada Mahasiswa Feb Untag Di Semarang). Media EKonomi Dan Manajemen, 30(1), 101-113.

Riyandika, M. (2013). Analisa Pengaruh Electronic Word of- Mouth, Argument Quality, Message Source Credibility Terhadap Brand Image dan Dampaknya pada Purchase Intention. Universitas Bina Nusantara. Jakarta.

Simamora.Bilson (2001). Memenangkan Pasar dengan Pemasaran Efektif dan Profitabel, Jakarta: Penerbit PT. Gramedia.

Wahyunanda,K.P.(2019),Sebanyak Inikah Jumlah Pengguna Instagram di Indonesia, diperoleh $\begin{array}{lll}\text { pada } & 22 & \text { Januari }\end{array}$ di: https://tekno.kompas.com/read/2019/12/23/14020057/sebanyak-inikah-jumlahpengguna-instagram-di-indonesia.

Xian, Gou Li, dkk. (2011). Corporate-, Product-, and User-Image Dimensions and Purchase Intentions. Journal of Computers, (6)9: 18751879 